\title{
Growth curves and genetic parameters in Nelore animals estimated by random regression models ${ }^{1}$
}

\section{Curvas de crescimento e parâmetros genéticos em animais da raça Nelore estimados por modelos de regressão aleatória}

\author{
Maurício Vargas da Silveira ${ }^{2 *}$; Júlio César de Souza ${ }^{3}$; Tássia Souza Bertipaglia ${ }^{4}$; \\ Paulo Bahiense Ferraz Filho ${ }^{3}$; Mariana Alencar Pereira ${ }^{5}$; Carlos Henrique \\ Cavallari Machado ${ }^{6}$
}

\begin{abstract}
The objective of this work was to estimate growth curves and genetic parameters from birth to 650 days of age of Nelore cattle raised in pasture in two production regions of the Mato Grosso do Sul State, Brazil (233,835 weight records from 47,459 cattle were analyzed). Genetic parameters were determined by random regression using Legendre orthogonal polynomials of cubic order, and age at weighing was considered in the model as a fixed effect to model the average growth trajectory. In the models, the effects of the contemporary group were considered as fixed and, as covariates, the animal age at weighing and the cow age at calving were nested in the animal age class (linear and quadratic effects), forming eight age classes. All models included the direct genetic additive, maternal genetic, and animal permanent environment as random effects, and the most appropriate model to describe the studied effects was defined according to the AIC and BIC criteria. Heritability estimates for birth weight varied between the two production regions, Campo Grande-Dourados (R1) and Alto Taquari-Bolsão (R2) and R1 (0.36 \pm $0.02)$ and $\mathrm{R} 2(0.28 \pm 0.03)$, and there were variations in the estimates at advanced ages. In both regions, the highest heritability values at 650 days of age were $0.47 \pm 0.03$ and $0.65 \pm 0.02$ for R1 and R2, respectively, with high heritability reflecting the high values of additive genetic variance. The random regression methodology was efficient in estimating growth curves and genetic parameters. Growth curves were different when they were estimated separately by sex, birth season, and production region. Genetic parameters estimated separately by region indicate differences in additive genetic variance, maternal additive, and animal permanent environment for weights up to 650 days of age.
\end{abstract}

Key words: Heritability. Legendre polynomials. Residual variances classes.

\section{Resumo}

O objetivo do trabalho foi estimar curvas de crescimento e parâmetros genéticos, do nascimento aos 650 dias de idade de bovinos da raça Nelore criados a pasto em duas regiões de produção do estado de

Parte da Tese de Doutorado do primeiro autor.

2 Consultor na área de Bovinos de Corte, Dr. em Ciência Animal, Universidade Federal do Mato Grosso do Sul, UFMS, Campo Grande, MS, Brasil. E-mail: mauriciozootecnia@gmail.com

3 Profs., UFMS, Campo Grande, MS, Brasil. E-mail: julio.souza@ufms.br; paulo.ferraz@ufms.br

$4 \mathrm{Dr}^{\mathrm{a}}$ em Genética e Melhoramento Animal, Universidade Estadual de São Paulo "Júlio de Mesquita Filho", UNESP, Jaboticabal, SP, Brasil.E-mail: tassia_bertipaglia@hotmail.com

5 Gerente de Melhoramento Genético do PMGZ Leite, Associação Brasileira dos Criadores de Zebu, ABCZ, Uberaba, MG, Brasil. E-mail: marianaalencar@abcz.org.br

6 Prof., Faculdades Associadas de Uberaba, FAZU, Uberaba, MG, Brasil. E-mail: carloshenrique.cavallari@fazu.br

" Author for correspondence 
Mato Grosso do Sul, Brasil (Foram analisados 233 registros de peso provenientes de 47.459 animais). Os parâmetros genéticos foram determinados por meio de regressão aleatória, utilizando polinômios ortogonais de Legendre de ordem cúbica, a idade a pesagem foi considerada no modelo como efeito fixo para modelar a trajetória média de crescimento. Nos modelos, os efeitos de grupo de contemporâneos foram considerados como fixos e, como covariáveis, a idade do animal (efeitos linear e quadrático), sendo construídas oito classes etárias. Todos os modelos incluíram os efeitos genético aditivo direto, genético materno e de ambiente permanente direto como aleatórios, e o modelo mais apropriado para descrever os efeitos estudados foi definido de acordo com os critérios AIC e BIC.As estimativas de herdabilidade para peso ao nascimento foram diferentes nas duas regiões produtoras, Campo Grande-Dourados (R1), e Alto Taquari-Bolsão (R2), R1 $(0,36 \pm 0,02)$ e R2 $(0,28 \pm 0,03)$, e para as idades avançadas ocorreram variações nas estimativas. Em ambas as regiões, os maiores valores de herdabilidade foram aos 650 dias de idade, $0,47 \pm 0,03$ e $0,65 \pm 0,02$, respectivamente para R1 e R2, sendo a alta herdabilidade reflexo dos altos valores de variância genética aditiva. A metodologia de regressão aleatória mostrou-se eficiente em estimar curvas de crescimento e parâmetros genéticos. As curvas de crescimento mostraram-se diferentes quando estimadas separadamente por sexo, estação de nascimento e região de produção. Os parâmetros genéticos estimados separadamente por região, indicam diferenças nas variâncias genética aditiva, aditiva materna e de ambiente permanente do animal para pesos até os 650 dias de idade.

Palavras-chave: Classes de variâncias residuais. Herdabilidade. Polinômios de Legendre.

\section{Introduction}

In genetic evaluations of beef cattle, body weights taken over the life of the animals are the main sources of information. To standardize the analysis, breeding programs establish standard ages at which weights are adjusted before being evaluated. This procedure can facilitate selection in the herd and allows for comparisons with other herds or regions but may decrease the precision in the genetic evaluation (BOLIGON et al., 2009; VALENTE et al., 2008).

Since all productive processes are directly related to growth, another way of describing animal growth is based on the growth curves estimation aiming, through selection, to change the growth curve shape as one of the ways to obtain animals that reach slaughter weight sooner without increasing the size of the animals (GARNERO et al., 2005; GONÇALVES et al., 2011). Several nonlinear models are used for growth studies in beef cattle. However, due to advances in computer science, more accurate methodologies, as in the case of random regression models that simultaneously estimate growth curves and genetic parameters, have also been used.

Most authors use regressions on Legendre polynomials to model longitudinal data
(ALBUQUERQUE; EL FARO, 2008; BERTIPAGLIA et al., 2015; NESER et al., 2012). This methodology allows estimating and predicting parameters and genetic values for any desired age without the need to pre-adjust the weights, even for ages that the animal has not been measured (ARAÚJO et al., 2016). In Brazil, random regression has been widely used in Nelore cattle population studies by considering the presence of residual variance heterogeneity, adjusting different estimates at different periods along the animals' growth trajectory, allowing greater precision in the genetic parameters estimates with higher accuracy in the genetic values predictions (ARAÚJO et al., 2016; BALDI et al., 2010). Some authors reported that this methodology was adequate to describe the changes in body weight variances with age for Canchim, Tabapuã, and Brahman cattle breeds (BALDI et al., 2010; BERTIPAGLIA et al., 2015; SOUSA JÚNIOR et al., 2010).

However, there are few studies estimating growth curves by random regression models, and they compare the differences that exist when these are estimated separately by sex, birth season, and production region. That is, few studies have considered the possibility that variance structures may be different in different environments. Different 
genetic covariance structures for each environment require particular selection strategies for different environments, as selection criteria established with predicted genetic values based on unsuitable genetic structures could result in unexpected differentiated genetic gains for each environment. Differences in the covariance structure between random regression coefficients might lead to different results if the random regression coefficients are used as a selection criterion. Thus, there is a need to characterize covariance structures for different environments (VALENTE et al., 2008).

Therefore, the objective of this study was to estimate the growth curves and genetic parameters from birth to 650 days of age of Nelore cattle raised in pasture in two production regions of the Mato Grosso do Sul State, Brazil, using random regression models.

\section{Material and Methods}

A total of 233,835 weight records from 47,459 cattle were analyzed using weight records from birth to 650 days of age of Nelore cattle raised in pasture in two production regions (Campo GrandeDourados: R1, and Alto Taquari-Bolsão: R2) in the Mato Grosso do Sul State, Brazil. The cattle were born between 1986 and 2012 and were acquired from the Brazilian Association of Zebu Breeders (ABCZ). The production regions were characterized and differentiated by Arruda and Sugai (1994) according to the production system, technology level, quality, and productivity of the resources and cattle herd racial type.

$$
y_{i j}=E F+\sum_{m=0}^{k b-1} \beta_{m} \phi_{m}\left(t_{i}\right)+\sum_{m=0}^{k a-1} \alpha_{m} \phi_{m}\left(t_{i j}\right)+\sum_{m=0}^{k m-1} \gamma_{m} \phi_{m}\left(t_{i j}\right)+\sum_{m=0}^{k p-1} \delta_{m} \phi_{m}\left(t_{i j}\right)+E_{i j}
$$

in which $y_{i j}$ is the real weight in the $i$ age of the $j$ animal; $E F$ is the set of fixed effects (GC); $\beta_{m}$ is the regression coefficient to model the population mean trajectory; is the regression function that
The data analyzed had genealogy and weighing records of animals weighing a minimum of $28 \mathrm{~kg}$ and a maximum of $532 \mathrm{~kg}$. The contemporary group (GC) was defined by farm, sex, birth season (rainy season: October to April, and dry season: May to September), and birth year.

To improve the data file quality, some restrictions were established: the only animals considered had a minimum of four weight measurements, minimum of five animals per age, and had at least two bulls with a minimum of eight sons within each contemporary group. All data file manipulation and variance analyses were performed using the GLM procedure by $\mathrm{SAS}^{\circledR}$ software (SAS Institute Inc., Cary, NC, USA).

In the models, the effects of the contemporary group were considered fixed and, as covariates, the animal age at weighing and the cow age at calving were nested in the animal age class (linear and quadratic effects) for a total of eight age classes. The direct genetic additive, genetic maternal, and animal permanent environmental effects were considered as random variables. In addition, the Legendre orthogonal polynomial of cubic order for the age of weighing was considered in the model as a fixed effect to model the population mean curve.

The residual variances were modeled using classes with five levels, since it was the one that best fit the analyses. The 5-level class was constructed by grouping the ages: from birth to 120 days, 121 to 205 days, 206 to 365 days, 366 to 550 days, and 551 to 650 days of age to determine whether residual variances change with age. The random regression model used can be represented by:

describes the population mean curve according to the animal age $\left(t_{i}\right)$; are the functions that describe the trajectory of each $j$ individual according to age (t) for the direct additive genetic, maternal genetic, 
and animal permanent environmental random effects; $\alpha_{\mathrm{m}}, \gamma_{\mathrm{m}}$, and $\delta_{\mathrm{m}}$ are the random regressors genetic additive, maternal, and animal permanent environmental; $\mathrm{kb}, \mathrm{ka}, \mathrm{km}$, and $\mathrm{kp}$ are the orders of the polynomials used for the effects described above; $E_{i j}$ is the random error associated with each $i$ age of $j$ animal. In matrix notation, the model used can be described as:

$$
\mathrm{y}=\mathrm{Xb}+\mathrm{Z}_{1} \mathrm{a}+\mathrm{Z}_{2} \mathrm{~m}+\mathrm{W}_{1} \mathrm{p}+\mathrm{e}_{\mathrm{ij}}
$$

$$
\mathrm{E}\left[\begin{array}{c}
y \\
a \\
m \\
p
\end{array}\right]=\left[\begin{array}{c}
X b \\
0 \\
0 \\
0
\end{array}\right] ; \quad V\left[\begin{array}{c}
a \\
m \\
p \\
e
\end{array}\right]=\left[\begin{array}{ccccc}
k_{a} \otimes A & 0 & 0 & 0 & 0 \\
0 & k_{m} \otimes A & 0 & 0 & 0 \\
0 & 0 & k_{p} \otimes I_{N_{A}} & 0 & 0 \\
0 & 0 & 0 & 0 & R
\end{array}\right]
$$

where $k_{a}, k_{m}$, and $k_{p}$ are the (co)variance matrices among the random regression coefficients for the direct additive genetic, maternal genetic, and animal permanent environmental effects; $A$ is the relationship matrix between individuals; $I$ is the identity matrix; $N_{A}$ is the number of animals with registration; $N_{M}$ is the number of mothers; and $\otimes$ is the Kroneker product between matrices. $R$ represents a diagonal block matrix containing the residual variances. This model assumes that there is no correlation between the random regression coefficients for direct additive genetic, maternal, and animal permanent environmental effects of the animal.

The results of each model selection criteria are expressed by comparison, since smaller values for AIC (AKAIKE, 1973) and BIC (WOLFINGER, 1993) indicate the best fit. The AIC and BIC criteria consider the lack of fit and the number of parameters estimated in the equation. These can be used to compare models with the same fixed effects but with different variance structures. The BIC is more rigorous because it assigns higher penalties to the models with the highest number of parameters. The information criteria are represented below:

$$
\begin{aligned}
& A I C=-2 x \ln L+2 x p \\
& B I C=-2 x \ln L+p x \log (N)
\end{aligned}
$$

where $y$ is the observations vector; $b$ is the fixed effects vector (including $E F_{i j}$ and $\beta \mathrm{m}$ ); $a$ is the random coefficients vector for the direct additive genetic effects; $m$ is the random coefficients vector for maternal genetic effects; $p$ is the random coefficients vector for the animal permanent environmental effects; $\mathrm{X}, \mathrm{Z}_{1}, \mathrm{Z}_{2}$, and $\mathrm{W}_{1}$ are the corresponding incidence matrices; and $e_{i j}$ is the residue vector.

The assumptions about the components are:

where $p$ is the number of model parameters; $N$ is the total number of observations; and $\ln L$ is the Napierian logarithm of the restricted maximum likelihood function.

The covariance components were estimated with animal models and random regression models using the standard maximum likelihood method $\left(10^{-8}\right)$ in the Wombat Statistical Program (MEYER, 2007). The AIREML algorithm was chosen by calculating the standard errors of the estimates.

Based on the criteria of AIC and BIC, it was determined that the models with 4, 3, and 2 orders, 5 levels of residual classes (leg432_5), and 24 parameters were the most suitable for growth curves and parameter estimates of the analyzed data.

\section{Results and Discussion}

All variation sources were highly significant $(\mathrm{p}<0.0001)$, which highlights the importance of understanding these factors (Table 1). The mean estimated by the least squares method was $219.8 \pm$ $36.7 \mathrm{~kg}$, which is similar to that found by Silveira et al. (2014), who analyzed the productive and reproductive traits of Nelore females exclusively raised in pasture in the Mato Grosso do Sul State, Brazil. 
Table 1. Summary of variance analysis for weights of Nelore breed animals at R1 and R2.

\begin{tabular}{lcc}
\hline Source of variation & DF & MS \\
\hline Bull (random) & 267 & $109648.0^{*}$ \\
Birth year & 26 & $272232.0^{*}$ \\
Birth season & 1 & $787331.0^{*}$ \\
Sex & 1 & $23452818.0^{*}$ \\
Production region & 1 & $6340147.0 *$ \\
Class & 7 & $211073352.0 *$ \\
AAC (linear) & 1 & $835045.0^{*}$ \\
AAC (quadratic) & 1 & $954337.0 *$ \\
Error & 233529 & $1348.0 *$ \\
\hline Average (kg) & 219.8 & \\
CV $(\%)$ & 16.7 & \\
R $(\%)$ & 83.4 & \\
\hline R & & \\
\hline
\end{tabular}

R1: Campo Grande-Dourados; R2: Alto Taquari-Bolsão; DF: degrees of freedom; MS: Mean Square; GC: number of contemporary groups; Class: animal age class; AAC: age at calving; CV: Coefficient of variation; $\mathrm{R}^{2}$ : Coefficient of determination; *: Significance level $(\mathrm{P}<0.0001)$.

The differences among animals born in selected it should be adjusted for the environmental production regions, birth season, and sex are shown in Table 2. The results show the importance of understanding the sources of variation that act on the evaluated traits, suggesting that when animals are effects. Doing so minimizes the influence on the examined traits, allowing for the selection of genetically superior animals to be parents of the next generations, ultimately raising the genetic gain.

Table 2. Averages \pm standard error according to production region, birth season, and sex of birth at 650 days of age in Nelore breed animals raised in the Mato Grosso do Sul State.

\begin{tabular}{lcc}
\hline Efect & & Mean \pm standard error \\
\hline Production region & R1 & \\
& R2 & $222.6 \pm 0.2^{\mathrm{a}}$ \\
Birth season & & $207.3 \pm 0.2^{\mathrm{b}}$ \\
& Dry & $216.7 \pm 0.2^{\mathrm{a}}$ \\
& Rainy & $213.1 \pm 0.1^{\mathrm{b}}$ \\
Sex & Male & \\
& Female & $225.4 \pm 0.2^{\mathrm{a}}$ \\
& & $204.4 \pm 0.2^{\mathrm{b}}$ \\
\hline
\end{tabular}

Means followed by different letters in the same column differ significantly $(\mathrm{P}<0.05)$; R1 = Campo Grande - Dourados; R2 = Alto Taquari - Bolsão. 
The animals born in the dry season were heavier $(227.18 \pm 93.67 \mathrm{~kg})$ than those born in the rainy season $(226.81 \pm 92.01 \mathrm{~kg})$ in the $\mathrm{R} 1$ region (Figure 1A) due to the greater supply of food in the period of rain. The same behavior can be observed for the R2 region (Figure 1B), where the mean weights were $211.43 \pm 85.89 \mathrm{~kg}$ and $207.25 \pm 84.57 \mathrm{~kg}$, respectively, for dry and rainy seasons.

The growth curves of the two regions show that the animals born in the dry season exhibited superior performance relative to those born in the rainy season, and they consequently had higher weights at 650 days of age. These results can be explained by the fact that the animals born in the dry season, mainly those born in August, had a better maternal environment. That is, the matrices reach the lactation peak at the beginning of the rainy season, which provides a better maternal ability, especially regarding milk production in cows.

Figure 1. Growth curves estimated by Legendre polynomials according to the birth season for the R1 region (Campo Grande - Dourados); Number of observations: dry season: 45,393; rainy season: 96,991; R2 (Alto Taquari - Bolsão); Number of observations: dry season: 29,770; rainy season: 61,681 .

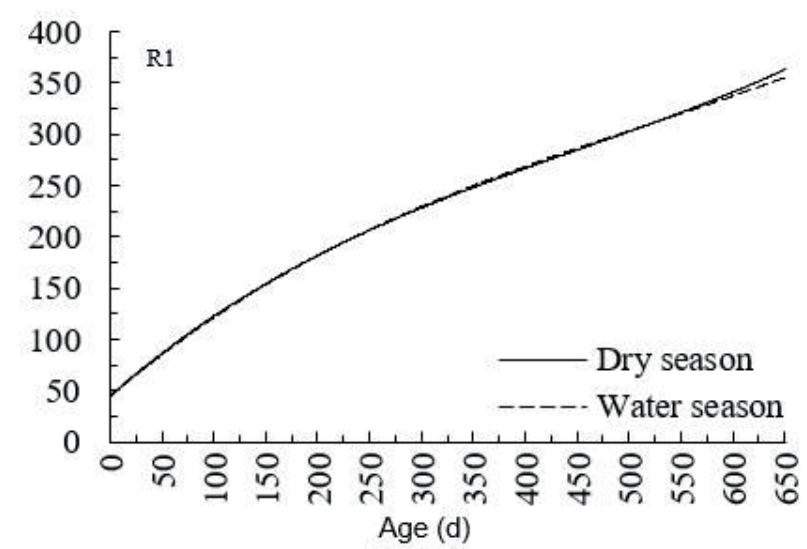

Thus, animals born in the dry season arrive at the subsequent drought with better body conditions since they took advantage of the best forage supply during the entire rainy season. Additionally, during the first days of their lives, these animals did not suffer infestations of endo- and ectoparasites, which are more prevalent in the rainy season. In the R1 region (Figure 1A), the growth curve of animals born in the two seasons were similar, which may be a consequence of the better production system and the adopted technology level.

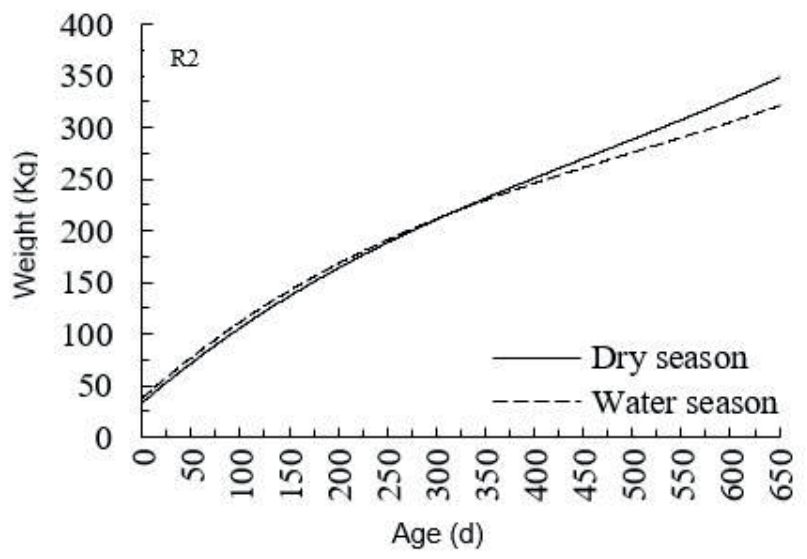

Figures $2 \mathrm{~A}$ and $2 \mathrm{~B}$ show the growth curves for males and females reared in the $\mathrm{R} 1$ and $\mathrm{R} 2$ regions, respectively. It was observed that males were heavier than females in both the R1 (males: 236.69 $\pm 97.63 \mathrm{~kg}$; females: $217.95 \pm 86.63 \mathrm{~kg}$ ) and R2 regions (males: $218.02 \pm 90.22 \mathrm{~kg}$; females: 198.73 $\pm 77.99 \mathrm{~kg}$ ), indicating sexual dimorphism for both regions, as reported by Santos et al. (2011) and Viu et al. (2006) in studies on Nelore cattle. 
Figure 2. Growth curves estimated by Legendre polynomials according to sex for the R1 region (Campo Grande - Dourados). Number of observations: female: 68,240; male: 74,144. R2 (Alto Taquari - Bolsão); Number of observations: female: 44,594; male: 46,857.

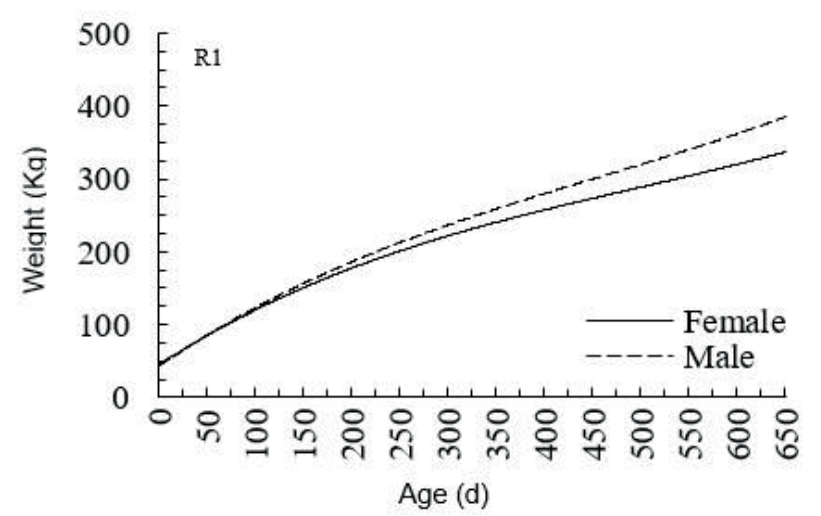

Figure 3 shows the growth curves for the two production regions (R1 and R2). Animals from the $\mathrm{R} 1$ region were heavier $(226.93 \pm 92.54 \mathrm{~kg})$ than those from the $\mathrm{R} 2$ region $(208.61 \pm 85.03 \mathrm{~kg})$. At 205 days of age, the animals of the two regions presented an average of approximately $200 \mathrm{~kg}$. After this age - likely due to weaning in the dry seasonthe growth rate decreased until approximately 500 days of age when it increased again. In addition, the use of more adequate genotypes and production systems may contribute to differences in animal performance in the different regions (TORAL et al., 2004). It is necessary to estimate genetic parameters such as heritability to guide the selection of animals

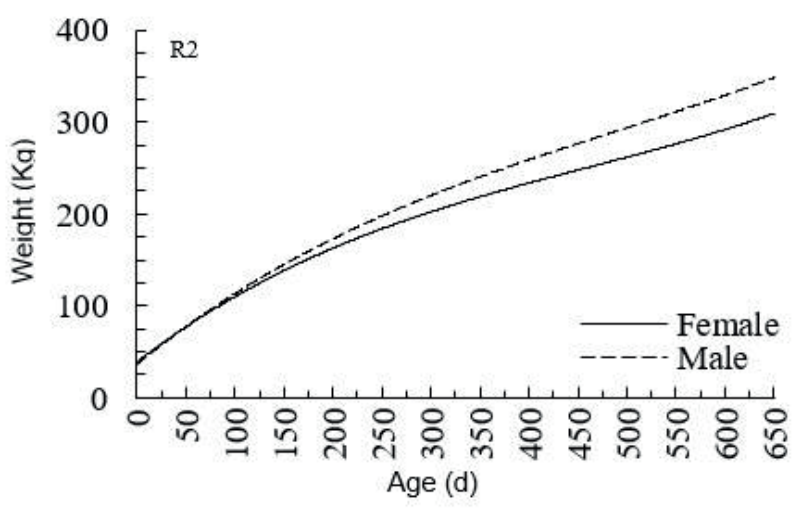

that present an early growth rate and that reach heavier weights at the slaughter age. The direct additive heritability estimates, maternal heritability (), and the animal permanent environment variance () as proportions of the total phenotypic variance for birth weights at 650 days of age using the random regression model for the two analyzed regions (R1 and R2) are shown in Figures 4-6. The regional division of observations allows different evaluations, which allows the comparison of variance structures as well as the direct and maternal heritability of the two regions. There is variance heterogeneity for direct and maternal additive genetic effects since their existence would indicate genotype $\times$ region interaction (VALENTE et al., 2008).

Figure 3. Growth curves estimated by Legendre polynomials according to the production region; R1: Campo Grande - Dourados; R2: Alto Taquari - Bolsão; Number of observations: R1: 142,384; R2: 91,451.

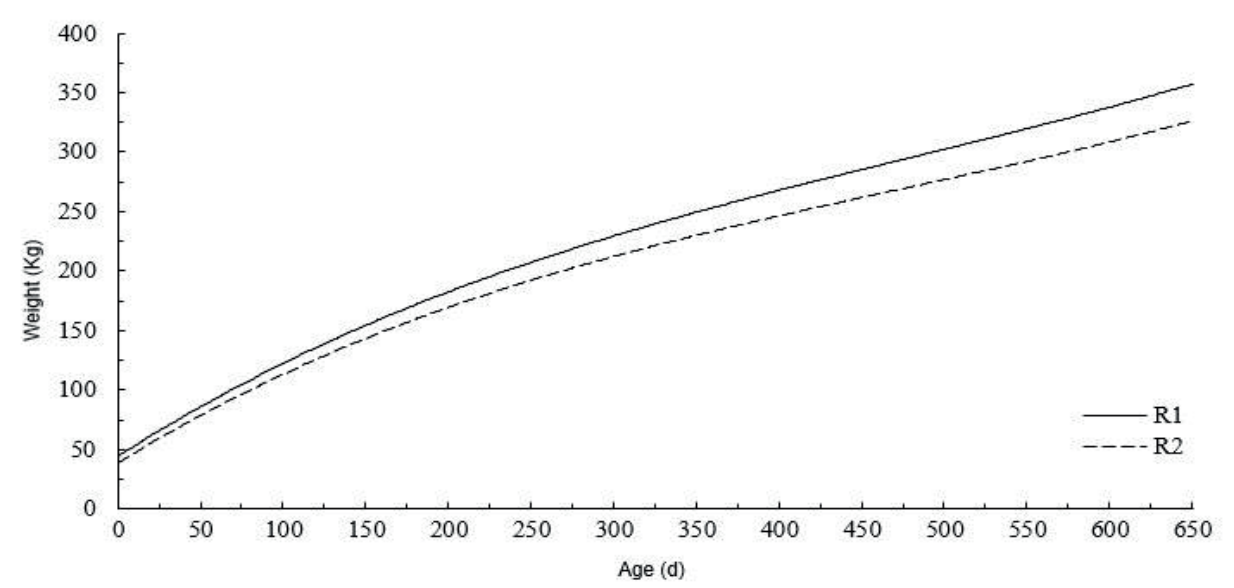


Figure 4. Direct additive heritability () estimated by means of random regression in the two production regions; R1: Campo Grande - Dourados; R2: Alto Taquari - Bolsão; Number of observations: R1: 142,384; R2: $91,451$.

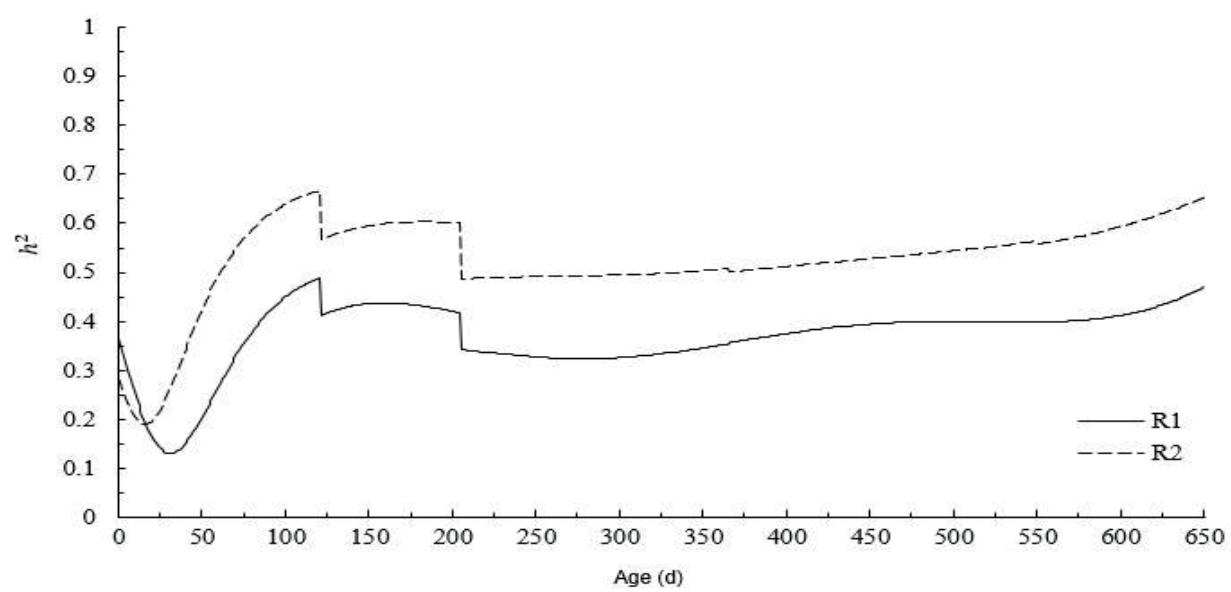

Figure 5. Maternal heritability () estimated by means of random regression in the two production regions; R1: Campo Grande - Dourados; R2: Alto Taquari - Bolsão; Number of observations: R1: 142,384; R2: 91,451.

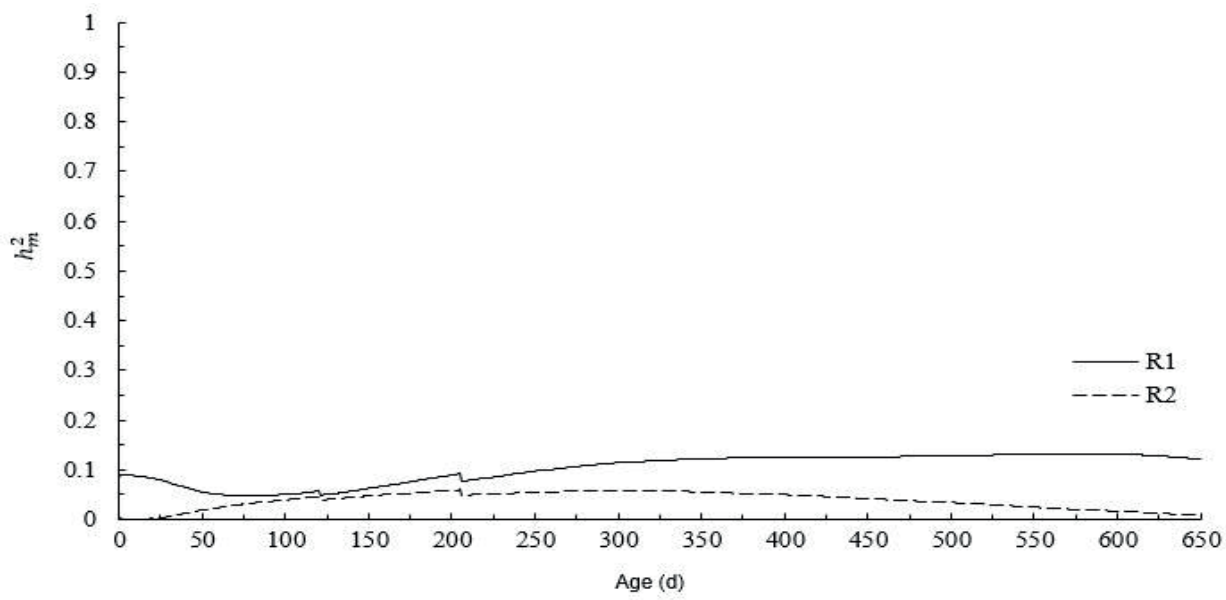

Figure 6. Variance estimates of the animal permanent environment as a proportion of the total phenotypic variance () by means of random regression in the two production regions; R1: Campo Grande - Dourados; R2: Alto Taquari Bolsão; Number of observations: R1: 142,384; R2: 91,451.

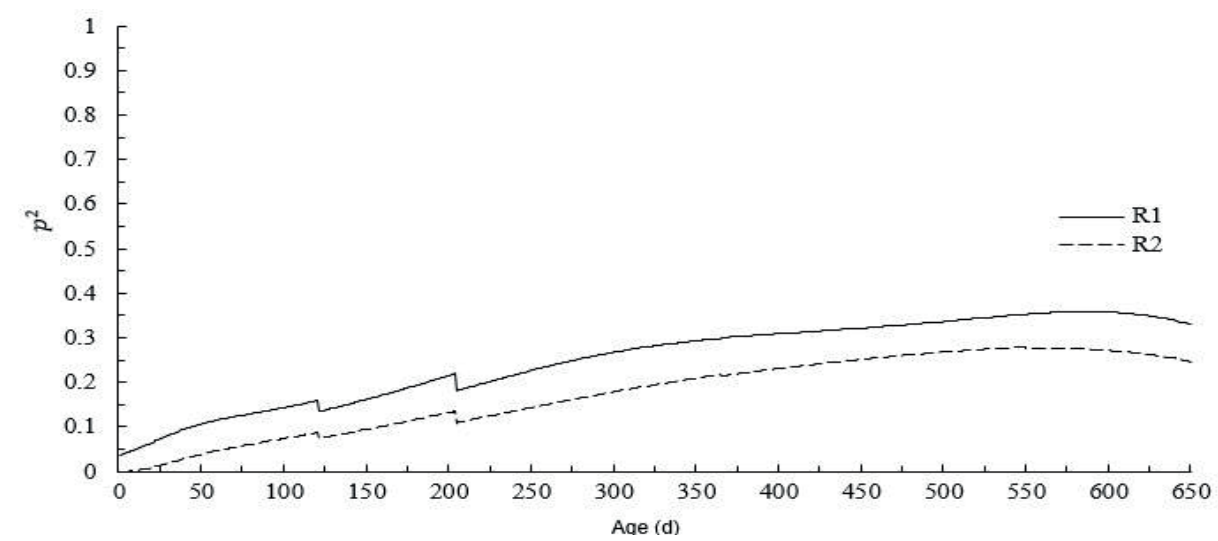


Estimates of $\mathrm{h}^{2}$ for birth weights of the $\mathrm{R} 1$ region were higher than those of $\mathrm{R} 2(0.36 \pm 0.02$ and $0.28 \pm 0.03$, respectively). After birth, there was a decrease until 32 days of age $(=0.13 \pm 0.02)$ for the $\mathrm{R} 1$ region, and for the $\mathrm{R} 2$ region the decrease occurred until 16 days of age $(=0.19 \pm 0.03)$. After these ages, the $\mathrm{h}^{2}$ increased again, and in both regions there was a maximum up to 120 days, where $\mathrm{h}^{2}$ values were $0.49 \pm 0.01$ and $0.67 \pm 0.02$ for $\mathrm{R} 1$ and $\mathrm{R} 2$, respectively.

After 120 days of age, estimates decreased again, and the lowest values for the $\mathrm{R} 1$ region were between 275 and 282 days of age $(=0.32 \pm 0.02)$; for $\mathrm{R} 2$, the lowest values occurred at 205 days of age ( = $0.49 \pm 0.02)$. In both regions, the highest heritability values were at 650 days of age, which were $0.47 \pm$ 0.03 and $0.65 \pm 0.02$ for $\mathrm{R} 1$ and $\mathrm{R} 2$, respectively, and the high heritability was a function of the high values of additive genetic variance. These results corroborate the findings of Bertipaglia et al. (2015) and Toral et al. (2014), who worked with random regression for weights of Brahman and Indubrasil cattle, respectively. Albuquerque and Meyer (2001) reported that direct heritability tended to be lower at ages in which maternal heritability presents higher values.

The maternal heritability () estimation for R 1 was $0.09 \pm 0.01$ at birth and decreased until 82 days of age $(:=0.05 \pm 0.01)$. It then increased and reached the highest value between 557 and 595 days of age ( $=0.13 \pm 0.01)$. For R2, the maternal heritability () estimation was $0.002 \pm 0.02$ at birth and increased until 120 days of age $\left(\mathrm{h}_{\mathrm{m}}^{2}=0.05 \pm 0.01\right) ;\left(\mathrm{h}^{2}{ }_{\mathrm{m}}=0.06\right.$ $\pm 0.01)$. It then decreased until 650 days of age at the minimum value $\left(\mathrm{h}_{\mathrm{m}}^{2}=0.01 \pm 0.01\right)$.

These results are similar to those of Baldi et al. (2010), who, using random regression, also observed the maternal heritability for Canchim cattle at birth $(0.05)$ to decrease after this period (0.02), increase at 400 days of age (0.03), and then decrease gradually until the end of the study period. The results observed in this study showed that the maternal effects begin to drop after birth with a subsequent increase, and it remains nearly constant probably due to the residual effect throughout the progeny's life (BERTIPAGLIA et al., 2015).

Higher response to selection for maternal ability may be expected if selection is performed based on weights close to weaning, since estimates of maternal genetic variance and maternal heritability increase during this period (BERTIPAGLIA et al., 2015). Similar results were reported by Dias et al. (2006) for Tabapuã animals.

It was observed that the R1 matrices presented variance estimates of animal permanent environment as a proportion of the total phenotypic variance () at birth and had values of $0.04 \pm 0.02$ and $0.000 \pm 0.04$ for R1 and R2, respectively. After birth, it increased until reaching the maximum value at $590(=0.36 \pm$ $0.02)$ and $545(=0.28 \pm 0.02)$ days of age in R1 and $\mathrm{R} 2$, respectively.

\section{Conclusions}

The random regression methodology was efficient in estimating the growth curves and genetic parameters of Nelore cattle in the present study. Growth curves estimated by random regression were different when estimated separately by sex, birth season, and production region.

Genetic parameters estimated separately by region indicate differences in genetic additive variance, maternal additive, and animal permanent environment for weights until 650 days of age.

\section{References}

AKAIKE, H. Information theory and an extension of the maximum likelihood principle. In: INTERNATIONAL SYMPOSIUM ON INFORMATION THEORY, 2., 1973, Budapest. Proceedings... Budapest: Academiai Kiado, 1973. p. 267-281.

ALBUQUERQUE, L. G.; EL FARO, L. Comparações entre os valores genéticos para características de crescimento de bovinos da raça Nelore preditos com 
modelos de dimensão finita ou infinita. Revista Brasileira de Zootecnia, Viçosa, MG, v. 37, n. 2, p. 238-246, 2008.

ALBUQUERQUE, L. G.; MEYER, K. Estimates of covariance functions for growth from birth to 630 days of age in Nelore cattle. Journal of Animal Science, Champaign, v. 79, n. 11, p. 2776-2789, 2001.

ARAÚJO, C. V.; NEHLS, W. F.; LAUREANO, M. M. M.; ZUBLER, R.; LÔBO, R. B.; FIGUEIREDO, L. G. G.; ARAÚJO, S. I.; BEZERRA, L. A. F. Modelos de regressão aleatória para características de crescimento de bovinos da raça Nelore do estado de Mato Grosso. Arquivo Brasileiro de Medicina Veterinária e Zootecnia, Belo Horizonte, v. 68, n. 2, p. 448-456, 2016.

ARRUDA, Z. J.; SUGAI, Y. Regionalização da pecuária bovina no Brasil. Campo Grande: EMBRAPA-CNPGC, 1994. $144 \mathrm{p}$.

BALDI, F.; ALBUQUERQUE, L. G.; ALENCAR, M. M. Random regression models on Legendre polynomials to estimate genetic parameters for weights from birth to adult age in Canchim cattle. Journal of Animal Breeding and Genetics, Medford, v. 127, n. 4, p. 289-299, 2010.

BERTIPAGLIA, T. S.; CARREÑO, L. O. D.; ASPILCUETA-BORQUIS, R. R.; BOLIGON, A. A.; FARAH, M. M.; GOMES, F. J.; MACHADO, C. H. C.; REY, F. S. B.; FONSECA, R. Estimates of genetic parameters for growth traits in Brahman cattle using random regression and multitrait models. Journal of Animal Science, Champaign, v. 93, n. 8, p. 3814-3819, 2015.

BOLIGON, A. A.; MERCADANTE, M. E. Z.; BALDI, F.; LÔBO, R. B.; ALBUQUERQUE, L. G. Multi-trait and random regression mature weight heritability and breeding value estimates in Nelore cattle. South African Journal of Animal Science, Pretoria, v. 39, n. 5, p. $145-$ 148, 2009.

DIAS, L. T.; ALBUQUERQUE, L. G.; TONHATI, H.; TEIXEIRA, R. A. Estimação de parâmetros genéticos para peso do nascimento aos 550 dias de idade para animais da raça Tabapuã utilizando-se modelos de regressão aleatória. Revista Brasileira de Zootecnia, Viçosa, MG, v. 35, n. 5, p. 1915-1925, 2006.

GARNERO, A. D. V.; MARCONDES, C. R.; BEZERRA, L. A. F.; OLIVEIRA, H. N.; LÔBO, R. B. Parâmetros genéticos da taxa de maturação e do peso assintótico de fêmeas da raça Nelore. Arquivo Brasileiro de Medicina Veterinária e Zootecnia, Belo Horizonte, v. 57, n. 5, p. 652-662, 2005.
GONÇALVES, F. M.; PIRES, A. V.; PEREIRA, I. G.; GARCIA, D. A.; FARAH, M. M.; MEIRA, C. T. CRUZ, V. A. R. Avaliação genética para peso corporal em um rebanho Nelore. Arquivo Brasileiro de Medicina Veterinária e Zootecnia, Belo Horizonte, v. 63, n. 1, p. 158-164, 2011.

MEYER, K. WOMBAT - A tool for mixed model analysis in quantitative genetics by restricted maximum likelihood (REML). Journal of Zhejiang University SCIENCE B, Zhejiang, v. 8, n. 11, p. 815-821, 2007.

NESER, F. W. C.; VAN WYK, J. B.; FAIR, M. D.; LUBOUT, P. Genetic evaluation of growth traits in beef cattle using random regression models. South African Journal of Animal Science, Pretoria, v. 42, n. 1, p. 474477, 2012.

SANTOS, G. C. J.; LIRA, T. S.; PEREIRA, L. S.; LOPES, F. B.; FERREIRA, J. L. Efeitos não genéticos sobre características produtivas em rebanhos Nelore criados na região norte do Brasil. Acta Veterinaria Brasilica, Mossoró, v. 5, n. 4, p. 385-392, 2011.

SILVEIRA, M. V.; SOUZA, J. C.; SILVA, L. O. C.; FREITAS, J. A.; GONDO, A.; FERRAZ FILHO, P. B. Interação genótipo $\mathrm{x}$ ambiente sobre características produtivas e reprodutivas de fêmeas Nelore. Archivos de Zootecnia, Córdoba, v. 63, n. 241, p. 223-226, 2014.

SOUSA JÚNIOR, S. C.; OLIVEIRA, S. M. P.; ALBUQUERQUE, L. G.; BOLIGON, A. A.; MARTINS FILHO, R. Estimação de funções de covariância para características de crescimento da raça Tabapuã utilizando modelos de regressão aleatória. Revista Brasileira de Zootecnia, Viçosa, MG, v. 39, n. 5, p. 1037-1045, 2010.

TORAL, F. L. B.; PEREIRA, J. C. C.; BERGMANN, J. A. G.; JOSAHKIAN, L. A. Parâmetros genéticos do peso desde o nascimento até 730 dias de idade na raça Indubrasil. Pesquisa Agropecuária Brasileira, Brasília, v. 49, n. 8, p. 595-603, 2014.

TORAL, F. L. B.; SILVA, L. O. C.; MARTINS, E. N.; GONDO, A.; SIMONELLI, S. M. Interação genótipo x ambiente em características de crescimento de bovinos da raça Nelore no Mato Grosso do Sul. Revista Brasileira de Zootecnia, Viçosa, MG, v. 33, n. 6, p. 1445-1455, 2004.

VALENTE, B. D.; SILVA, M. A.; SILVA, L. O. C.; BERGMANN, J. A. G.; PEREIRA, J. C. C.; FRIDRICH, A. B.; FERREIRA, I. C.; CORRÊA, G. S. S. Estruturas de covariância de peso em função da idade de animais Nelore das regiões Sudeste e Centro-Oeste do Brasil. 
Arquivo Brasileiro de Medicina Veterinária e Zootecnia, Belo Horizonte, v. 60, n. 2, p. 389-400, 2008.

VIU, M. A. O.; LOPES, D. T.; GAMBARINI, M. L.; OLIVEIRA FILHO, B. D.; FERRAZ, H. T.; MAGNABOSCO, C. U.; VIU, A. F. M. Efeito da época do parto, idade materna e sexo sobre o desempenho pré-desmama de bezerros Nelore (Bos taurus indicus), criados extensivamente no centro-oeste do Brasil. Archives of Veterinary Science, Curitiba, v. 11, n. 3, p. 75-79, 2006.

WOLFINGER, R. Covariance structure in general mixed models. Communications in Statistics - Simulation and Computation, Ontario, v. 22, n. 4, p. 1079-1106, 1993. 
